\title{
Endüstriyel Futbolda Finansal İstikrarın Önemi ${ }^{l}$
}

\section{Ahmet Hilmi YILMAZ ${ }^{2}$}

\section{The Importance of Financial Stability in Industrial Football}

\begin{tabular}{l} 
ARTICLE INFO \\
\hline Article History: \\
Date Submitted:16.04.2020 \\
Date Accepted:16.05.2020 \\
\hline JEL Classification: \\
L80, \\
L83, \\
L89.
\end{tabular}

Keywords:

Football,

Industry,

Globalization,

Financial Discipline,

Financial Stability.

\begin{abstract}
With the establishment of the British Football Federation in 1863, football, which was accepted as an official sport, has spread rapidly all over the world. The professionalization process in football, which started especially from the second half of the 1990s, has transformed the sports activities from being a game into an economically functioning field. As a result of these developments, the values of the capitalist order began to dominate football. With the transformation of football into a new understanding of football, which has been rapidly industrializing, diversity and volume increased in the income and expense items of the clubs. This situation necessitated that clubs operating under the status of associations change the management understanding of the high budget clubs and that these clubs should be institutionalized and have a more institutional structure. As a result, the growth in the football industry brought along the need for fiscal discipline. In this study the structure formed by the industrialization of football, financial stability which is of great importance within the structure considered and factors that lay the groundwork for financial instability with due regard to the current financial indicators of Beşiktaş Gymnastic Club, Fenerbahçe Sport Club and Galatasaray Sport Club are analyzed and policy recommendations are made.
\end{abstract}

\footnotetext{
${ }^{1} \mathrm{Bu}$ makale, yazar tarafından hazırlanmakta olan "Endüstriyel Futbolda Yönetim Parametreleri ve Finansal İstikrarsılıklar" başlıklı yüksek lisans tezinden türetilmiştir.

2 İstanbul Ticaret Üniversitesi, Sosyal Bilimler Enstitüsü, İktisat Bölümü, ahmethilmiyilmaz37@gmail.com
} 


\section{Özet}

1863 yılında İngiltere Futbol Federasyonu'nun kurulmasıyla birlikte resmi anlamda spor olarak kabul edilen futbol, hızlı bir şekilde tüm dünyaya yayılmıştır. Özellikle 1990'lı yılların ikinci yarısından itibaren başlayan futboldaki profesyonelleşme süreci, sportif etkinlikleri bir oyun olma özelliğinden çıkartarak ekonomik düzeyde işleyen bir alana dönüştürmüştür. Bu gelişmelerin bir neticesi olarak ise kapitalist düzenin değerleri, futbola da egemen olmaya başlamıştır. Futbolun, hızla endüstrileşen yeni bir futbol anlayışına dönüşümüyle birlikte, kulüplerin gelir ve gider kalemlerinde de çeşitlilik ve hacim artışı gerçekleşmiştir. $\mathrm{Bu}$ durum, özellikle dernek statüsünde faaliyet gösteren yüksek bütçeli kulüplerin yönetim anlayışlarını değiştirmesini ve söz konusu kulüplerin şirketleşerek daha kurumsal bir yapıya sahip olmasını gerekli kılmıştır. Bunun sonucunda da futbol endüstrisinde gerçekleşen büyüme, mali disiplin ihtiyacını beraberinde getirmiştir. Bu çalışmada, futbolun endüstrileşmesiyle birlikte oluşan yapıya ve söz konusu yapı içerisinde büyük bir önem arz eden finansal istikrara değinilerek, Beşiktaş Jimnastik Kulübü, Fenerbahçe Spor Kulübü ve Galatasaray Spor Kulübü’nün güncel finansal göstergeleri ile finansal istikrarsızlığa zemin hazırlayan faktörleri incelenmiş ve nihai olarak ise politika önerilerinde bulunulmuştur.

Anahtar Kelimeler: Futbol, Endüstri, Küreselleşme, Mali Disiplin, Finansal İstikrar

\section{Giriş}

Futbol kavramı uzun soluklu tarihi bir geçmişe dayanmaktadır. Türk Dil Kurumu (TDK), futbolu "topu, kafa veya ayak vuruşları ile karşı kaleye sokma kuralına dayanan ve on birer kişilik iki takım arasında oynanan top oyunu, ayak topu” olarak tanımlamaktadır. Başka bir tanıma göre ise futbol, oyuncuların oyun kuralları gereği, belirlenmiş bir alanda oynadıkları ve sonucun da kalelere atılan gollerle belirlendiği, el harici, vücudun her yerini kullanarak oynanan bir spor dalı olarak karşımıza çıkmaktadır (İnal, 1998, s. 17).

Futbolun tarihsel sürecini incelediğimizde ise, tarihte futbola benzeyen ve ayakla oynanan bir oyuna ilk kez, M.Ö. 5000-2500 yıllarında Çin ve Mısır'da rastlandığı saptanmıştır. Çin'de oynanan ve futbolla büyük bir benzerlik gösteren bu oyuna "Tsu Chu” denmektedir. Futbol, Çin'den sonra M.Ö. 1004 yılında Japonya'da görülmüştür. Yine bu oyunun Amerika 
kıtasında ise M.Ö. 1500’lü yıllarda Aztekler tarafından oynandığı tahmin edilmektedir. Yunanlıların oynadığı oyun ise 12 kişilik takımlardan oluşan ve rugby gibi el de kullanılabilen bir yapıdadır. Romalıların Yunanlılardan alarak değiştirdikleri ve nihayetinde de "Harpastum" olarak anılan oyun, modern futbolun öncüsü olarak ifade edilmektedir. Bu oyunun tarihsel boyutu 12. yüzyıla kadar uzanmakla birlikte, günümüz futbolu resmi anlamda ilk olarak 19. yüzyılın sonlarında İngiltere'de ortaya çıkmıştır (Erdoğan, 2008, s. 11-16).

1750’li yıllarda İngiltere'de başlayan ve insanların hayatlarında köklü değişikliklere neden olan Sanayi Devrimi'nin etkisiyle, dokuma atölyelerinde işçi olarak çalışan köylü çocukları, futbolu boş buldukları geniş alanlarda oynamaya başlayarak yaygınlaştırmıştır. 1880'li yıllara gelindiğinde ise İngiltere'de futbolun orta sınıftan ziyade işçi sınıfının da önemli bir eğlencesi olduğu görülmüştür (Hür, 2002, s. 60-65). Bu bakımdan, modern futbolun doğuşunda ve gelişiminde Sanayi Devrimi’nin beraberinde getirdiği şehirleşmenin büyük etkisinin olduğunu söylememiz mümkündür. Özellikle 1860’lı yıllardan sonra, işçi sınıfının çalışma saatlerinin düzenlenmesi, kırsal kesimden kentlere göç eden insanların kent yaşamına uyum sağlaması, işçi sınıfı arasında yeni bir futbol kültürü yaratmıştır (Yurdesin, 2005, s. 111). 1863 yılında İngiltere Futbol Federasyonu'nun (Football Association) kurulmas1 ve futbolun kurallarının belirlenmesi ile bu süreç resmiyet kazanmıştır (Wahl, 2005, s. 17). 1857 yılında ilk futbol kulübünün İngiltere'de kurulmasının ardından, 1888 yılında 12 tane kulübün bir araya gelmesiyle profesyonel futbol ligi oluşturulmuştur. Daha sonra 1904 yılında FIFA (Federation Internationale de Football Association) kurulmuş ve 1906 yılında uluslararası müsabakaların yapılmasına karar verilmiştir (Erdoğan, 2008, s. 14). İngiltere'de 19. yüzyılda bir işçi sınıfı eğlencesi olarak karakterize edilen futbol, söz konusu gelişmelerle birlikte, İngiliz denizciler tarafından başta İberya Krallı̆̆ı, İskandinavya, Şili, Arjantin, Uruguay ve Brezilya olmak üzere tüm dünyaya yayılmış ve zamanla bu branşa olan ilgi artmıştır (Yurdesin, 2005, s. 109).

Hayatın akışı içinde var olan iddialı olma, rekabet etme, heyecan yaratma, haz ve mutluluk verme ve hatta hüzünlendirme gibi duyguları içinde barındıran futbol, bu nedenle bireyler arasında her yaş grubundan ve her kesimden insan için popüler bir hale gelmiştir (Kuper, 1996). Futbolun, her gelir seviyesinden insanın, yaşadıkları mahalle veya sokaklarda, kaleyi işaret eden sadece iki taş ve bir topla oynayabileceği basit bir oyun olması onun popülaritesini artırmaktadır (Alpman, 2004, s. 7). Futbolu popüler kılan bir diğer özelliği ise 
takım sporu olmasıdır. Kolektif spor dalları, bireysel spor dallarına nispeten daha fazla izlenmekte ve oynanmaktadır (Sert, 2000, s. 43-44). Bununla birlikte, futbolun bu kadar ön planda olmasının nedeni, futbolun rekabet duygusu, kazanma ve yaşama bir anlam katma gibi insani duyguları ortaya çıkarması ve erişiminin kolay olmasından kaynaklanmaktadır. $\mathrm{Bu}$ sebeplerden dolayı futbol, günümüzde oldukça geniş bir hacme ulaşmıştır.

Bu çalışmanın birinci bölümünde literatür taramasına yer verilmiş, ikinci bölümünde futbolun endüstrileşme süreci, üçüncü bölümünde futbolun ticarileşmesi, dördüncü bölümünde futbol endüstrisinin aktörlerine değinilmiştir. Beşinci bölümde, güncel veriler 1şığında Türkiye'deki üç büyük kulübün finansal göstergeleri incelenmiş ve nihai olarak ise sonuçlar kısmında, elde edilen sonuçlara ve söz konusu sonuçlara istinaden politika önerilerine yer verilmiştir.

\section{Literatür Taraması}

İktisat, her şeyden önce sosyal ve toplumsal bir bilimdir. Özellikle futbolun endüstriyel bir süreç içerisine girerek piyasa halini almasıyla birlikte, iktisat ve futbolun birbirine yakınlaştığ 1 ve birçok ekonomistin çalışmalarında futbola da yer verdiği görülmüştür.

Ulusal literatürde futbol ve futbol endüstrisine yönelik Futbol ve Futbolu İnceleme (Erdoğan, 2008), Futbolun Kültür Kodları (Gülhan, 2019), Kapitalist Bir Etkinlik Olarak Futbolun Büyüsü ve Kahramanları (Kılınç, 2008), Kapitalizm Sürecinde Futbolun Ticarileşmesi (Yiğit, 2012), Küreselleşme ve Futboldaki Dönüşüm (Akkaya, 2008), Endüstriyel Futbol (Akşar, 2005), Futbol Değil İş: Endüstriyel Futbol (Talimciler, 2008), Endüstriyel Futbol Üzerine Bir Araştırma (Kiraz, 2016), Endüstriyel Futbol ve Futbolda Teknoloji Kullanımı (Demir, 2019), Futbolun Ekonomi Politiği (Akşar, 2010), Krizdeki Futbol (Akşar, 2013), Avrupa Futbol Pazarının Ekonomik Boyutu ve Avrupa Futbol Kulüplerinde Finansal Performans Analizi (Güngör, 2014), Futbol Endüstrisinde Sportif Başarı ile Finansal Performans Arasındaki İlişkinin Analizi ve Türkiye Uygulaması (Güngör, 2014), Süper Lig Futbol Kulüplerinin Finansal Performans Analizi (Uluyol, 2014), Finansal Fair Play ve Türkiye'deki Dört Büyük Futbol Kulübünün Uyum Düzeyinin İncelenmesi (Saban ve Demirci, 2016), Futbolda Finansal Sürdürülebilirlik Kapsamında "Finansal Fair-Play Başa Baş Kuralı" 
ve Beşiktaş Futbol Kulübü Üzerinde Bir Uygulama (Aktaş ve Mutlu, 2016), Türk Futbol Kulüplerinin Finansal Yeniden Yapılanması ve Yönetişimsel Sorunlarına Çözüm Önerileri (Akşar, 2011), Türkiye'de Futbolun Kurumsal Değişimi (Batmaz vd., 2017), Kurumsal Yönetim İlkeleri Işığında Türk Futbol Kulüpleri Yönetim Rehberi (Türkiye Kurumsal Yönetim Derneği, 2010) ve Türk Futbolunda Kurumsal İletişim Yönetimi (Katırc1, 2009) gibi çalışmalar; uluslararası literatürde ise Futbol Asla Sadece Futbol Değildir (Kuper, 1996), The New Football Business: A Challenge for Elite Followers (Marquez ve Martin, 2001), Ayaktopu: Futbolun Öyküsü (Wahl, 2005), The İmportance of Market Size in The Consumer Service Professional Football: The Belgian Case (Dejonghe, 2008), The Application of the Business System Concept to the Analysis of Football Business (Karpavicius ve Jucevicius, 2009), Football Supporters and The Commercialisation of Football: Comparative Responses Across Europe (Kennedy ve Kennedy, 2012), Commercialization Strategies in Football (Krabbenbos, 2013), Logic of Appropriateness in Football Commercialization: The Case of UEFA Champions League (Mariotti, 2014), Commercialization of European Football (Bhandari, 2016), Football Sponsorship Market: Danish Perspective (Schoop, 2016) gibi çalışmalar incelenmiştir. Ayrıca söz konusu çalışmalarda futbol, endüstriyel futbol, futbolun ticarileşmesi, futbolun ekonomik boyutu, futbolun basın ve medya ile olan ilişkisi, futboldaki sponsorluk uygulamaları ve pazarlama süreci, futbolun değişen taraftar yapısı, futbol endüstrisindeki rekabetçi denge analizi, sportif başarı ile finansal başarı arasındaki ilişki, kulüplerin şirketleşerek halka açılma süreçleri ve markalaşma çalışmaları, futbolun kurumsal yönetimi ve kulüplerin uygulamış oldukları iletişim modelleri gibi konulara değinildiği saptanmıştır.

Bu çalışmanın ise çok büyük bir kısmı futbol ve futbol endüstrisi etrafında kümelenmiş olsa da nihai olarak kulüpler açısından finansal istikrarın önemine değinilmiş ve ülkemizdeki üç büyük kulübün yapmış oldukları son Divan Kurulu toplantılarında kamuoyuna açıkladıkları konsolide borç rakamları derlenerek, söz konusu kulüplerin içerisinde bulunmuş oldukları durumdan nasıl çıkabileceklerine dair politika önerilerinde bulunulmuştur. Özellikle futbol ve futbol endüstrisine ilişkin hem ulusal ve hem de uluslararası literatürde yer alan çalışmalarda finansal istikrara ya da istikrarsızlığa zemin hazırlayan faktörlere çok fazla yer verilmediği ve olaylara daha bütüncül bir şekilde yaklaşıldığı görülmektedir. Bu bağlamda, bu çalışma biraz daha spesifik bir çalışma olarak karşımıza çıkmaktadır. 


\section{Futbolun Endüstrileşme Süreci}

Futbol, sahibi olduğu özellikler itibariyle, kapitalist sistem içerisinde amacından saptırılarak istismar edilebilen bir unsur haline gelmiştir. Futbolu amacından saptıran ve söz konusu oyunu haz veren, sade ve eğlenceli bir oyun olmaktan ziyade, kapitalist düzeyde işleyen bir etkinliğe dönüştüren en önemli faktör ise, futbolun bireylerin beklentilerine karşıllk veren atmosferidir (Kılınç, 2008, s. 276). Bununla birlikte futbol, toplulukları etkisi altında bırakan ve ekonomik anlamda oldukça önemli yatırımların yapıldığı bir spor dalı olarak karşımıza çıkmaktadır. Bu bağlamda, taraftarın tüketici konumuna gelerek talep tarafını oluşturduğu ve buna karşın futbol kulüplerinin de arz eden tarafta olduğunu görülmektedir. Oluşan bu yapı, futbolu, arz ve talebin belirli bir fiyatta buluştuğu bir endüstri konumuna taşımaktadır. Bu kapsamda futbol, sportif içerikli bir kavram olmaktan ziyade, endüstriyel bir kavram olarak nitelendirilmektedir. Futbolun endüstriyel bir yapıya bürünerek piyasa halini alması, zaman içerisinde futbolun karakteristik yapısında önemli değişikliklere yol açmıştır. Gelinen noktada futbol, üreticisi, tüketicisi, medya ve iletişimi, ürünü, ürününün pazarlanması, arzı, talebi ve dağıtımıyla birlikte önem arz eden bir endüstriye dönüşmüştür.

Benzer malların üretimini gerçekleştiren firmalar topluluğu olarak karşımıza çıkan endüstri kavramı, herhangi bir üretim dalında faaliyet gösteren firmaların bir araya gelmek suretiyle oluşturmuş oldukları üretim alanını ifade etmektedir (Türkbal, 1983, s. 258). Futbol endüstrisi ise, futbol kulüplerinin bir araya gelerek ortaya çıkardığı futbola ilişkin ürün ve hizmetler olarak tanımlanabilir. Futbol endüstrisini diğer endüstri dallarından ayıran özellikler, rekabet koşulları, tüketici kitlesinin çeşitliliği ve rasyonel olmayan tüketici davranışları gibi birtakım yapısal farkl1lıklardan kaynaklanmaktadır (Güngör, 2014, s. 18). Bu durum, bireylerin futbola olan yoğun ilgisi, tutkusu ve ön plana çıkardığg duygularını, ticari kaygılar haline getirerek futbolun küresel ölçekli endüstriyel bir piyasa haline gelmesine neden olmaktadır. Bu piyasa içinde de futbol, maddi bir bedel karşılığında yapılan, bir temaşa sanatına dönüşmektedir. $\mathrm{Bu}$ bağlamda futbol endüstrisi, futbolun haz veren görsel bir şov haline getirilerek paylaşıldığı ve söz konusu paylaşımların da ticari bir faaliyet olarak değerlendirildiği bir tür endüstri modeli olarak karşımıza çıkmaktadır. Gelinen noktada futbol endüstrisi, futbolun işleyişine yardımcı olan aktörlerin ortaya çıkardığı katma değerle, ekonominin önemli bir mihenk taşı olmuştur. 
Futbola olan ilginin artması, sermayedarların dikkatini bu oyun üzerine yoğunlaştırmalarına neden olmuştur. Futbol, sermayedarlar için yeni ekonomik kazanımlar yaratmanın yollarını açmıştır. Fabrika takımları arasındaki karşılaşmaların büyük ilgi görmesi, yeni bir sektörün oluşmasına neden olmuş ve futbol beraberinde futbol endüstrisini yaratmıştır. Bununla birlikte futbolun modern anlamda endüstrileşmesi son otuz yıl içerisinde gerçekleşmiştir. FIFA, çok uluslu şirketlerin sponsorluğuna açtığı Dünya Kupası organizasyonunu 1982 yılından itibaren "top sponsorluk" uygulaması ve turnuvaya katılan ülke sayısını 16'dan önce 24'e ardından da 32'ye çıkartarak başlatmıştır. Diğer bir gelişme ise, UEFA (Union of European Football Associations) tarafından 1992-1993 sezonunda başlatılan Şampiyonlar Ligi uygulamasıdır. Bu organizasyon ile futbolun endüstriyel boyutu ön plana çıkartılmıştır (Demir, 2019, s. 89-90).

Günümüzde büyük bir endüstri alanı olan futbolun, özellikle 1980’li yıllardan sonra daha çok ön plana çıkmasında, dünyada yaşanan ekonomik gelişmelerin yanı sıra, ekonomik sistemler ile futbol arasındaki yoğun ilişkinin de önemli bir yeri bulunmaktadır. Söz konusu y1llarda dünyada yaşanan liberal dalgalanma, futbolu da etkilemiş, bu durum futbolun endüstrileşme sürecinin hızlanmasına neden olmuştur. Kültürel faktörler ile ekonomik faktörlerin birlikte değerlendirildiği bu dönemde, kültür sanayileri (kitle iletişim araçları, turizm, serbest zaman faaliyetleri, spor vb. gibi) ekonomik perspektiften bakıldığı takdirde vazgeçilmez faaliyetler olarak değerlendirilmektedir (Talimciler, 2010). Yine söz konusu y1llarda kapitalizmin önemli bir unsuru olan tüketimin, kitlelere benimsetilmesinde, kitleleri etkileme gücü yüksek olan futboldan yararlanılmıştır. Futbolun geniş kitleleri etkileyebilme gücü, tüketim ideolojisi ile birleştirildiğinde, serbest piyasa ekonomisi için vazgeçilmez bir sektörün yaratılmasına imkân sağlamıştır (Talimciler, 2008, s. 92). Bu sektörün temel yapısı incelendiğinde endüstrileşme sürecinin, futboldaki taraftar profilini, kulüplerin gelir kaynaklarının yapısını, taraftarların davranış kalıplarını ve kulüplerin fonksiyonel yapılarını (sportif yapıdan, ekonomik yapıya) değiştirdiği görülmektedir (Türkiye Kurumsal Yönetim Derneği, 2010, s. 13-14). 


\section{Futbolun Ticarileșmesi}

Futbolun yasal, yönetsel ve ekonomik yapısında yaşanan dönüşüm ticarileştirme kavramı ile açıklanabilir. Futboldaki ticarileşme kavramı, futbol sayesinde oluşan ekonomik ve finansal değerlerin toplamını ifade etmektedir. Bu kavramın beraberinde getirdiği ticarileşme süreci ise, futbol tüketicisine atfedilen önemi artırmaya katkıda bulunmaktadır. Futbolun ortaya çıktığı ilk yıllarda kulüpler maksimum kâr elde etme hedefi yerine, sportif başarıyı hedeflemiş ve bu hedefe ulaşarak taraftarlarını memnun etme amacını gütmüştür. Fakat zaman içerisinde futbol, profesyonel anlamda liglerin ve FIFA başta olmak üzere uluslararası federasyonların organize ettiği turnuvaların oluşmasıyla ticari bir faaliyet alanına dönüşmüştür. Bu bağlamda, futbolun, İkinci Dünya Savaşı'ndan önce de Avrupa'nın çeşitli bölgelerinde ticari bir ürün olarak kabul gördüğü söylenebilir. Finansal sermayenin futbol içerisinde önemli bir yere sahip olduğu konjonktürde, kulüplerin ekonomik olarak güçlü olmaları ve diğer kulüplerle rekabet edebilmeleri için ticarileşme sürecine uyum sağlamaları gerekmektedir. Bundan dolayı 1990'lı yıllardan sonra profesyonel anlamda faaliyet gösteren birçok futbol kulübü, şirketleşerek tüzel bir kişiliğe bürünmüştür (Bhandari, 2016, s. 17).

Futbolun endüstrileşme süreciyle birlikte, kulüpler söz konusu endüstriden daha fazla pay alabilme, kurumsallaşarak daha profesyonel bir yapıya sahip olma, gelir kalemlerini artırma, sermaye piyasalarından düşük maliyetli ve daha uzun vadeli fonlar sağlayabilme gibi amaçlar doğrultusunda şirketleşmeyi ve şirketleşme sürecinin devamında da halka açılma gibi bir yolu izlemişlerdir (Devecioğlu vd., 2012, s. 36). Genel olarak dernek statüsünde faaliyet gösteren kulüpler, dernek olmanın getirdiği vergisel avantajın yanı sıra kamu kuruluşlarından yardım alabilme, izin almaksızın ayni ya da nakdi bağış toplayabilme ve gayrimenkul edinebilme gibi haklara sahiptir. Özetle, kulüpler dernek olmanın her türlü yasal ve yönetsel avantajlarından ciddi derecede faydalanmaktadır. Fakat günümüz itibariyle kulüplerin milyon dolarlara ulaşan bütçeleri, dernek yapılanması içerisinde yönetilememektedir. Ayrıca, dernek olduklarından dolayı herhangi bir ticari faaliyette bulunamayan kulüpler, bu sorunu şirketleşerek gidermeye çalışmaktadır (Akşar, 2005). Bu sayede, dernek olmanın beraberinde getirdiği ticari faaliyet sınırlılığını ortadan kaldıran kulüpler, aynı zamanda farklı gelir kaynakları aracılığıyla nakit akışlarında süreklilik sağlamayı hedeflemektedir. 
Kulüplerin şirketleşmesiyle birlikte, futbolda finansal sermayenin rolü, ciddi derecede artış göstermiştir. 1990'lı yıllardan önce, kulüplerin hedefi sporcu bulmak ve bulunan sporculardan oluşturulan takımların sportif başarı elde etmesi olarak karşımıza çıkarken, günümüzde ise elde edilecek sportif başarılarla taraftarları memnun etmek ve futbol endüstrisinin oluşturduğu kâr ve faydayı maksimize etmektir. Kulüpler için asıl olan, söz konusu hedeflere ulaşmanın yollarını bulmak olduğu söylenebilir (Krabbenbos, 2013, s. 8). Yaklaşık bir asırdır herhangi bir ticari unsurdan etkilenmeyen futbol, 1900'lü yılların başlarında ilk özel mülkiyet haklarının bulunduğu İngiltere'de bile, ulusal federasyon kurallarının, kulüplerin temettü ödeme politikalarındaki sınırlama yoluyla, oyunun deforme edilmesine ve özel çıkarların etkisinden korunmasına yönelik olduğu görülmüştür. Ancak özellikle 1990’l1 yıllardan itibaren kulüpler gelirlerini artırmayı amaçlamış ve doğal olarak futbolda ticarileşme sürecine girilmiştir. Bu durumun nedenlerinden bazıları şunlardır (Marquez ve Martin, 2001, s. 120);

- $\quad$ Sahadaki performans ve gelir arasındaki ilişki

- $\quad$ Oyuncuların maaşlarındaki artış eğilimi

- $\quad$ Oyuncular için daha yüksek transfer özgürlüğü

- $\quad$ Kulüpler arasında en iyi oyuncular için yaşanan yüksek rekabet

- $\quad$ Diğer endüstriler için futbolun keşfi (TV, radyo, spor giyim, vb.)

- $\quad$ Uluslararası turnuvalardaki önemli ödüller

Bunlar, futbolun ticari bir faaliyet olarak ortaya çıkmasının bazı olası nedenleri olarak kabul görmektedir. Özellikle de televizyonun varlı̆̆ı ve yayın hakları için yapılan teklifler, futbol endüstrisinin boyutunu ortaya çıkarmakta ve ekonomik hacminin artmasını sağlamaktadır.

\subsection{Medya ve İletişim}

20. yüzyıldan itibaren başlayan ve günümüzde de artarak devam eden teknolojik gelişmeler ile medyanın gücü artmıştır. Medyanın artan bu gücü ise kitlesel tüketimi artırmış ve futbolun ticarileşmesine imkân tanımıştır. Aynı anda binlerce insanı hem stadyumlara hem de ekrana çekme özelliğine sahip olan futbol, medyanın da etkisiyle dünyanın her yerinde 
geçerliliği olan bir yapı haline bürünmüştür (Akbulut, 2018). Futbol müsabakaları, kulüpler ve sporcular, genel olarak medya için, özel olarak ise televizyon için büyük bir öneme sahiptir. Toplumun futbola olan yoğun ilgisi, yüksek izlenme oranları, reklam ve sponsorluk anlaşmaları derken, müsabakaların yayın hakları, televizyon kanallarının en çok ilgi gösterdikleri yapımlar olmakta ve günümüz itibariyle bu alanda yaşanan hem ulusal hem de uluslararası rekabetin oldukça ciddi boyutlara ulaştığı görülmektedir (Talimciler, 2010).

Futbol, endüstriyel bir sürece girmesiyle birlikte başta televizyon olmak üzere, reklam ve sponsorluk gibi tüketim ile ilişkili nosyonlar çerçevesinde oynanan bir oyun olarak karşımıza çıkmaktadır. Özellikle oynanan maçların canlı yayınlar aracılığıyla seyircilere aktırılması televizyona olan bağımlılığı artırmıştır. Artan bu bağımlılık neticesinde, seyircilerin ilgisini çekecek ve kulüplere maddi olarak daha fazla gelir getirecek turnuvaların düzenlemesi, gerçeği ortaya çıkmıştır (Demir, 2019, s. 92). Bu gerçeğe istinaden, özellikle FIFA ve UEFA gibi uluslararası federasyonlar tarafından düzenlenen turnuvalar, futbol endüstrisinin en önemli gelir kalemlerinden olan çok uluslu şirketlerin futbola daha fazla yatırım yaparak söz konusu kulüplerle reklam ve sponsorluk anlaşmaları imzalamalarına olanak sağlamıştır.

Canlı olarak yayınlanan futbol müsabakaları ya da futbol yayınları esnasında televizyonlarda seyircinin ilgisini çeken reklamlar yer almaktadır. Yayını yapan kanal hem seyirciler hem de reklam veren kişi ya da kurumlar üzerinden maddi bir kazanç elde etmektedir. Elde edilen bu kazancın ölçeği, söz konusu yayınların izlenme oranlarına göre belirlenmektedir. Reyting adı verilen bu oranlar sayesinde, televizyon kanalları seyircilerin nicel çoğunluğu, yaş ve cinsiyet gibi özelliklerini kullanarak, reklam veren kişi ya da kurumlar üzerinde güçlü olmak ve bu sayede de söz konusu yayınları pazarlamak istemektedir. Bu açıdan bakıldığı takdirde, futbol endüstrisinin, medya tarafından beslendiği ve sermaye sahiplerinin de futbola yönelmesine öncülük ettiği söylenebilmektedir (Akbulut, 2018).

\subsection{Bosman Kuralları ve Transfer Sistemi}

Futbolun küresel bir yapıya bürünerek ticarileşmesinde Bosman Kuralları da önemli bir yer tutmaktadır. Belçikalı futbolcu Jean-Marc Bosman'ın başrolde olduğu, 1990 yılında başlayan ve beş yıllık bir hukuksal mücadele sonucunda ortaya çıkan Bosman Kuralları, futbol 
adına büyük bir değişimi ifade etmektedir. Royal FC Liege'de forma giyen Jean-Marc Bosman, bir süre sonra Fransa 2. Ligi'nde mücadele eden Dunkerque kulübüne transfer olmak istemiştir. Fakat kulübünün, Dunkerque kulübünden istemiş olduğu yüksek bonservis bedelinden dolayı, transfer gerçekleşmemiştir. Bu olaydan sonra Bosman'ın girişmiş olduğu hukuksal mücadele, lehine sonuçlanmış ve mahkemenin almış olduğu kararlar "Bosman Kararı” olarak kayıtlara geçmiştir. Bu kararla birlikte, kulüpleriyle yapmış oldukları sözleşmesi sona eren futbolcular, istedikleri kulüple sözleşme yapabilme özgürlüğüne kavuşmuştur (Akşar, 2005, s. 11). Ayrıca futbolculara transfer özgürlüğü tanıyan bu kararların sonucunda, özellikle küresel boyuttaki futbolcu hareketliliği büyük bir ivme kazanmış ve bu durum da futbolun ticarileşme sürecini hızlanmıştır. Yine bu karar, futbolun bir oyun olmaktan çıkarak endüstriyel düzeyde işleyen bir sektör haline dönüşmesine zemin hazırlayan bir karar olarak da karşımıza çıkmaktadır.

\section{Futbol Endüstrisinin Aktörleri}

Futbol endüstrisi, günümüz itibariyle piyasa dinamikleriyle işleyen kolektif bir yapı olarak değerlendirilmektedir. Piyasalar, birtakım aktörleri beraberinde getirmekte ve bu aktörlerden bağımsız olarak ele alınamamaktadır. Futbolun endüstrileşme süreciyle birlikte, futbolun içerisinde var olan aktörlerin yapısında da birtakım değişiklikler yaşanmıştır. Futbolun ortaya çıktığı ilk yıllarda sadece kulüpler, futbolcular ve taraftarlardan oluşan ana aktörler, futbolda yaşanan dönüşümün ardından ciddi derecede artış göstermek durumunda kalmıştır. Günümüz itibariyle endüstriyel futbolun başlıca aktörleri arasında kulüpler, futbolcular ve menajerler, taraftarlar, federasyonlar, yayıncı kuruluşlar, sponsorlar ve tedarikçiler, finansal kuruluşlar ve devlet gibi aktörler gösterilebilir. Futbol, her ne kadar bu aktörler ekseninde cereyan eden bir oyun olarak karşımıza çıksa da sektör içerisinde çalışan ve katma değer yaratan antrenör, fizyoterapist, masör, kondisyoner, malzemeci, kulüp personeli, aşçı, şoför, güvenlik ve tesis görevlisi, mağaza çalışanı ve sekreter gibi diğer emekçilerin varlığı da söz konusudur.

\subsection{Kulüpler}

Gerek profesyonel gerekse amatör sporcuların bir araya gelerek, takımlar halinde sportif müsabakalara çıkmasına olanak sağlayan yapıya kulüp denmektedir. Kulüpler, inşa etmiş oldukları altyapı sistemleriyle, söz konusu sporcuların çalışarak hem fiziki hem de teknik 
anlamda kendilerini geliştirmesine imkân tanımaktadır (Tutal, 2013, s. 272). Aynı zamanda kulüpler, futbolun endüstriyel bir sürece girmesiyle beraber, futbolu ilgilendiren mal veya hizmetlerin üretilmesini sağlayan birincil kaynak olarak da karşımıza çıkmaktadır. Ayrıca, futbolun ortaya çıktığı ilk yıllardan beri amatör bir anlayışla yönetilen kulüpler, endüstrileşme sürecinin getirdiği zaruri hususlarla birlikte, profesyonelliğin ön planda olduğu kurumsal bir yönetim anlayışına geçmek durumda kalmıştır (Katırcı, 2009, s. 66-67). Genel olarak dernek statüsünde kurulan ve faaliyetlerine de yine dernek statüsünde devam eden kulüpler, futbolun endüstrileşmesiyle birlikte, oluşan yeni yapıdan daha fazla pay alabilme ve kurumsallaşarak, daha profesyonel bir yapıya sahip olma gibi amaçlar doğrultusunda şirketleşmek durumunda kalmıştır. Haliyle bu durum, kulüplerin kâr etme güdüsüyle hareket etmelerini de beraberinde getirmiştir. Günümüz itibariyle kulüplerin, sportif başarının yanında finansal başarının da ön planda olduğu bir organizasyon yapısına büründüğü görülmektedir.

\subsection{Futbolcular ve Menajerler}

Futbolcular, futbola dair yetenekleri olan ve söz konusu yeteneklerini de futbolun kuralları çerçevesinde yeşil sahalarda sergileyen sporculardır. Futbolcular, yeşil sahalarda sergilemiş oldukları yeteneklerinin ya da başka bir ifadeyle emeklerinin farklı kulüpler tarafından satın alınması veya kiralanmasının bir ifadesi olan transfer süreçleriyle metalaştırılmakta ve finansal bir varlık olarak kabul görmektedir. Endüstriyel futbolda metalaşan futbolcunun değeri, futbol piyasasının ekonomik yapısı tarafından belirlenmektedir. $\mathrm{Bu}$ yapı futbolcuların emeğini kullanırken, futbolu ise topluma, şöhret kazanarak varlıklı olmanın bir yolu olarak sunmakta ve kapitalist sistemi de meşru bir hale getirmektedir (Erdoğan, 2008, s. 24). Futbol endüstrisinde üretici pozisyonunda yer alan futbolcular, kulüplerin ve liglerin varlığını etkileyen önemli bir aktör olarak karşımıza çıkmaktadır. Futbolcuların mesleki becerileri, kulüplerin veya liglerin başarısını ve kârlılığını direkt olarak etkilemektedir (Karpavicius ve Jucevicius, 2009, s. 87). Söz konusu durum, zaman içerisinde futbolcuların maddi bir bedel karşılığında, alınıp satılabilen bir ürün muamelesi görmesine neden olmuştur.

Bununla birlikte, üçüncü bölümde "Futbolun Ticarileşmesi” kısmında yer verdiğimiz Bosman Kuralı'nın yürürlüğe girmesiyle beraber, futboldaki transfer piyasası da yeniden 
şekillenmek durumunda kalmıştır. Futbolcuların söz konusu piyasada özgürce hareket etmesini sağlayan bu kurallar, aynı zamanda da futbolcular için kulüplere verilecek olan bonservis bedelleri ve futbolculara ödenecek olan aylık ya da yıllık ücretlerde ciddi artışların yaşanmasına neden olmuştur. Bunun sonucunda yaşanan hacim artışı ise, menajerlik gibi bir mesleğin oluşumuna zemin hazırlamıştır. Menajerler, yurtiçinde ya da yurtdışında temsil haklarını satın aldıkları futbolcuların transferlerine aracılık etme misyonunu üstlenen ve futbolcular üzerinden maddi olarak bir kazanç elde ederek piyasayı kontrol altında tutmak isteyen aracı kişilerdir. Ayrıca menajerler, transfer süreçleri dışında, söz konusu futbolcuların mevcut kulüpleriyle olan ticari ilişkilerini de yürütme ve futbolcuları yönlendirme yetkinliğine sahiptir.

\subsection{Taraftarlar}

Taraftarlık olgusu, bireylerin herhangi bir kulüple duygusal ya da zihinsel bir bağ kurmak suretiyle, kendilerini söz konusu kulübe ait hissetme durumu olarak ifade edilebilir. $\mathrm{Bu}$ olgunun en belirgin özelliği ise, rasyonel bir yapı üzerine inşasının mümkün olmaması olarak karşımıza çıkmaktadır (Talimciler, 2017, s. 28). Rasyonel bir karar alma sürecinden ziyade duygusal bir yaklaşım temelinde ortaya çıkan taraftarlık olgusu ve aidiyet duygusu, söz konusu bireylerin hayatına direkt olarak etki eden bir durumdur. Bu durum göz önüne alındığı takdirde, taraftarlık olgusunun oldukça önemli bir olgu olduğunu söylememiz mümkündür.

Taraftarlığın önemli olması ya da başka bir ifadeyle cazibesinin yüksek olması, taraftarların aidiyet hissettikleri kulüpler sayesinde, kendilerini daha güvenli bir yerde konumlandırma arzusundan kaynaklanmaktadır. Taraftarlar, söz konusu kulüpler aracılığıyla kendilerini bir topluluğa ait hissetme ihtiyacını karşılamaktadır. Bu durumun en temel faktörü olan kulüpler ise, simgesel de olsa taraftarlarının kişiliklerinin bir modülü olarak işlev görmekle birlikte, taraftarların ilgisinden faydalanarak, ulusal ya da uluslararası tanınırlıklarını artırma hedefini karş1lamaktadır (Talimciler, 2017, s. 37). Futbolun endüstriyel bir süreç içerisine girmesiyle birlikte, taraftarlık olgusu, yerini müşteri olgusuna bırakmaktadır. Günümüz itibariyle, futbol endüstrisi içinde yer alan taraftarlar, tüketici konumuna gelmesi nedeniyle futbol endüstrisinin talep kısmını oluşturmaktadır. 
Kulüpler, tüketici konumundaki taraftarlar sayesinde arz ettikleri ürünlerin talebi konusunda herhangi bir sıkıntı çekmemekte ve ürünlerini kolay bir şekilde satabilmektedir. Ayrıca futbol sektörü, diğer sektörlere göre esnek olmayan bir talebe sahiptir. Bu durumun en önemli ve belirgin nedeni taraftarların kulüplerine olan aidiyetleridir. Öyle ki, kulüplerin arz ettiği tüm ürünler, taraftarlar tarafından sorgulanmaksızın satın alınarak 'bağlılık körlüğü' olarak tabir edilen, tüketim harcaması alışkanlığını nüksettirmektedir. Kulüplerin sportif anlamda kötü bir performans sergiledikleri dönemlerde bile söz konusu durum devam etmektedir. Taraftarların gösterdiği bu tutum, kulüplerin gelir kalemlerini çeşitlendirerek, gelirlerini artırmasını ve futbol endüstrisinin de daha hızlı bir şekilde büyümesini sağlamaktadır (Akşar, 2009).

\subsection{Federasyonlar}

Aynı alanda faaliyet gösteren kurum ya da kuruluşların bir araya gelmesiyle oluşturulan toplulukları ifade eden federasyon kavramı, futbol özelinde değerlendirildiğinde, futbolun bir tür yönetim organı olarak karşımıza çıkmaktadır. Söz konusu organı, genel itibariyle kıtasal ve kıtalararası olmak üzere ikiye ayırmamız mümkündür.

\subsubsection{Kitalararası Federasyonlar}

21 Mayıs 1904 tarihinde Paris’te kurulan FIFA ya da tam açılımıyla Uluslararası Futbol Federasyonları Birliği (Fransızca: Fédération Internationale de Football Association), futbol ve futsalın dünya çapındaki en üst düzey yönetim organıdır. Merkezi İsviçre'nin Zürih kenti olan FIFA'nın başkanlığını İsviçreli Gianni Infantino yürütmektedir. Bünyesinde, 211 ulusal futbol federasyonunun üyeliğini bulunduran FIFA, çeşitli futbol turnuvalarını düzenlemesinin yanı sıra dünya futbolunu yöneten, kuralları uygulayan, değiştiren bir kurum olarak karşımıza çıkmaktadır. Düzenlemekte olduğu en önemli turnuva ise 1930 'dan bu yana her dört yılda bir gerçekleştirilen FIFA Dünya Kupası'dır (Vikipedi).

\subsubsection{Kitasal Federasyonlar}

FIFA üyesi olan tüm ulusal futbol federasyonları, bulunduğu kıtanın konfederasyonuna üye olmaktadır. Kıtasal şampiyonalar düzenleyen bu konfederasyonlar FIFA'nın bir alt kademe 
yönetim organı konumundadır (FIFA). 15 Haziran 1954'te İsviçre'nin Basel şehrinde 31 ulusal futbol federasyonunun bir araya gelmesiyle kurulan ve günümüz itibariyle bünyesinde 55 ulusal futbol federasyonunun üyeliğini bulunduran UEFA ya da açılımıyla Avrupa Futbol Federasyonları Birliğgi, FIFA'ya bağlı altı konfederasyonun en büyügüdür. Ayrıca yine diğer konfederasyonlar içerisindeki en güçlü mali ve sportif altyapıya sahip olan bir kurum olarak kabul görmektedir (UEFA, 2019). Bununla birlikte, her dört yılda bir, üye federasyonların milli takımlar düzeyinde temsil edildiği Avrupa Futbol Şampiyonası ve kendi liglerinde başarı elde eden kulüp takımlarının katılım sağladığı UEFA Şampiyonlar Ligi ve UEFA Avrupa Ligi gibi uluslararası düzeyde üç farklı organizasyon düzenlemektedir.

UEFA dişında, Asya'da futbolu organize eden ve yöneten AFC, Afrika'da futbolu organize eden ve yöneten CAF, Kuzey ve Orta Amerika ile Karayipler Futbol Konfederasyonu olan CONCACAF, Güney Amerika'da futbolu organize eden ve yöneten CONMEBOL ve son olarak Okyanusya'daki OFC gibi kıtasal federasyonlar da ulusal haklarını ihlal etmeden FIFA'ya destek sağlamaktadır. (FIFA).

\subsection{Yayıncı Kuruluşlar}

Dünya üzerindeki tüm futbol organizasyonlarını seyircilere aktarma hakkına ve imkanına sahip olan televizyonlar, futbolu yerel özelliklerinden arındırarak, futbola evrensel bir anlam yüklemek ve kulüpler ile futbolcuların tanınmasını sağlamaktadır. Bu durum hem kulüplerin hem de futbolcuların popülerliğini artırarak gelirlerini yükseltmektedir (Ekmekçi vd. 2013, s. 103). Bu açıdan bakıldığında, futbolun tüm paydaşları için, müsabakaların yayınlanması son derece önemlidir. Bu yayınlar, ilgili federasyonlar tarafından pazarlanmakta ve bu sayede yayıncı kuruluş kavramı ortaya çıkmaktadır. Yayıncı kuruluşlar, futbolseverlerin söz konusu futbol müsabakalarını izleyebilmeleri açısından önemli misyona sahiptir.

Ulusal ya da uluslararası futbol federasyonların açmış olduğu yayın ihalelerini alarak, yayıncı kuruluş olma hakkına sahip olan televizyon kanalları ise, yayın haklarını almış oldukları müsabakaları, seyircilere maddi bir bedel karşılığında satmakta ve hem yapılan satışlardan hem de reklamlardan ciddi bir kazanç elde etmektedir (Akkaya, 2008, s. 10). 


\subsection{Sponsorlar ve Tedarikçiler}

Futbol, yüzyıllardır uygulanmakta olan bir spordur, ancak futbol aynı zamanda milyonlarca dolarlık bir endüstridir. Her yıl ülkeler arasında giderek artan oranda daha güçlü, önemli ve sevilen bir endüstri halini almıştır. Futbolda sponsorluklara harcanan paraların toplamı her yıl futbola olan ilgiyle birlikte artmakta ve günümüzde kulüpler sponsorluktan yılda ortalama 200 milyon dolardan fazla kazanmaktadır. Günümüzde yerel, ulusal veya uluslararası bir şekilde sponsorluk almayan bir kulüp bulmak neredeyse imkansızdır. Çünkü sponsorluklar şirketin farkındalığını artırmakta, belirli bir kulüple ilişkilerini geliştirmekte ve kulüpler de bu yolla kendilerine finansal bir destek almaktadır. Bunlar, bir şirketin sponsorluğa girmesinin nedenlerinden bazılarıdır. Sponsorluk aynı zamanda taraftarlar nezdinde şirketin itibar elde etmesini sağlar. Ancak daha da önemlisi, belirli bir hedef kitle kapsamında marka bilinirliğine yol açabilmektedir. Şirketlerin, tüketicilerin futbol kulüpleriyle duygusal bağları nedeniyle sponsor olmaları muhtemeldir. Duygusal bağlantı güçlü bir etkendir ve şirketler bu pazarlama yaklaşımını etkili bir pazarlama aracı olarak görmektedir (Schoop, 2016, s. 1). Sponsorluk uygulamasından yararlanacak olan paydaşların amacı, söz konusu anlaşmalardan elde edilen gelir sayesinde, kendilerini fonlayarak sportif anlamda başarılı olmak ve nihai olarak da hem taraftarlarını hem de sponsorlarını memnun etmektir. Buna karşın sponsorların amacı ise, sponsor oldukları kulüpler üzerinden reklamlarını yapmak suretiyle hem marka değerlerini yükseltmek hem de tüketicilerin zihinlerinde markalarıyla ilgili olumlu bir izlenim bırakmak olduğu söylenebilir. Bununla birlikte gerek kulüplerin gerekse sporcuların bir nevi sponsor mahiyetindeki tedarikçilere ihtiyacı vardır. Türk Dil Kurumu'nun güncel sözlüğüne göre, tedarikçi "gerekli malzemeyi sağlayan kimse" olarak ifade edilmiştir (TDK). Başka bir ifadeyle, herhangi bir ürünün piyasaya sunulması için faaliyet gösteren firmalara ham madde ve ürün sağlayan toptancı konumundaki üreticiye tedarikçi denmektedir. Günümüz itibariyle Adidas, Nike, Puma, Coca Cola ve Pepsi gibi firmalar, futbol endüstrisi içerisinde tedarikçi konumunda yer almaktadır. Özellikle kulüpler için büyük bir öneme sahip olan futbol topları, maç formaları, antrenman ürünleri, eşofman takımları ve tişört gibi lisanslı ürünlerin üretilmesi ve üretilen bu ürünlerin de global anlamda pazarlanabilmesi için bir tedarikçiye ihtiyaç duyulmaktadır. Bu açıdan bakıldığında tedarikçi firmalar, anlaşmalı oldukları kulüpler için bir nevi sponsorluk görevi de üstlenmektedir. 


\subsection{Finansal Kuruluşlar}

Futbol endüstrisi içerisinde nihai olarak başarılı olma hedefi güden kulüpler, nakit akışlarında problem yaşadıkları ya da gelirlerinin yetersiz olduğu durumlarda kısa vadeli ödemelerini bankalar, borsalar, aracı kurumlar, yatırım ortaklıkları, portföy yönetim şirketleri, yatırım danışmanlık şirketleri, faktoring şirketleri, leasing (finansal kiralama) şirketleri ve sigorta şirketleri gibi çeşitli finansal kuruluşlar aracılığıyla yapabilmektedir. $\mathrm{Bu}$ açıdan bakıldığında söz konusu finansal kuruluşlar, özellikle kulüpler açısından önemli bir konuma sahiptir.

\subsection{Devlet}

Futbol, endüstrileşme sürecine girmesiyle birlikte, kabuk değiştirmiş ve günümüz itibariyle oldukça yüksek bir hacme sahip bir sektör haline gelmiştir. Futbol sektörünün hacmi ile vergi matrahı aynı oranda büyümektedir. Bu doğrultuda da denetim mekanizmalarından biri olarak işlev görmekte olan devlete önemli görevler düşmektedir. Çünkü devlet, yükümlülüklerini tam ve eksiksiz olarak yerine getirdiği takdirde, gelirlerini artırmış olacaktır. Bununla birlikte, özellikle Türkiye gibi gelişmekte olan ülkelerde devlet, çeşitli kamu kuruluşları vasıtasıyla sponsorluk anlaşmaları yapmakta ve söz konusu anlaşmalar sayesinde kulüplere mali anlamda destek sağlamaktadır. Ayrıca yine futbolun hemen her şeyinden kazanç sağlanmaya çalışıldığı günümüzde, devletin lisans verdiği bahis şirketlerinin varlığı da söz konusudur.

\section{Türkiye’deki Üç Büyük Kulübün Finansal Göstergeleri}

Günümüz itibariyle futbol, neredeyse dünyanın en büyük endüstrisine sahip bir oyun olarak karşımıza çıkmaktadır. Futboldaki dönüşümle birlikte yaşanan hacim artışı, futbol endüstrinin içerisinde maddi olarak yüksek rakamların dolaşımını da zorunlu kılmaktadır. Küreselleşme dalgalarının da etkisiyle şirketleşerek daha kurumsal bir yapıya dönüşen ve kendi ekonomik değerlerini yaratma güdüsüyle hareket eden kulüplerinin, özellikle küreselleşme dalgalarının yoğunlaştığı son yıllarda ciddi bir mali çıkmazın içerisine girdiği görülmektedir. Gerçekleşen hacim artışına ayak uydurmakta zorlanan kulüplerin, sağlıklı bir finansal yapıdan uzaklaşarak maddi yükümlülüklerini yerine getiremez bir hale geldiği söylenebilir. 
Kulüplerin mali yapılarındaki dalgalanmaların temelinde ise, gelir ve giderlerindeki makasın açılması sonucunda ortaya çıktığı gözlemlenen finansal anlamdaki istikrarsızlıklar yer almaktadır. Elde ettikleri gelirden fazla harcama yapan kulüpler, var olan krizi daha da derinleştirmekte ve bunun sonucunda ise borçlar sürdürülemez bir boyuta gelmektedir. Borç kavramı temel olarak, kulüplerin zarar etmesinden kaynaklanan nakit akışındaki açığını kapatmak ya da maddi yükümlülüklerinin yerine getirilmesini sağlamak amacıyla belli bir faiz oranı ve vade ile genellikle bankalardan alınan ayni ya da nakdi edimler olarak karşımıza çıkmaktadır. Özellikle günümüz koşullarında ülkemizdeki neredeyse tüm kulüplerin en büyük sorununun sürekli olarak artış eğilimde olan borç yapısı olduğu söylenebilir. Öyle ki, bu durum artık kulüpler tarafından kontrol edilebilir olmaktan çıkmıştır. Söz konusu durumu daha somut bir biçimde ele almak adına, Türkiye'deki üç büyük kulübün son Divan Kurulu toplantılarında kamuoyuna açıklamış oldukları güncel borç rakamları derlenmiştir. Buna göre;

Beşiktaş Jimnastik Kulübü’nün 15 Şubat 2020 tarihinde yapmış olduğu 2020 Y1lı 1. Olağan Divan Kurulu Toplantısı'nda kulübün ve bağlı ortaklıklarının toplam borcu 2.961.902.493 TL olarak açıklanmıştır. Beşiktaş JK Divan Kurulu üyeleriyle paylaşılan Beşiktaş JK Denetim Kurulu'nun 2019 Y1lı 4. Dönem Raporu incelendiğinde, söz konusu borcun 604.288.770 TL’sinin Beşiktaş Jimnastik Kulübü Derneği ve bağlı şirketlerine, 2.357.613.723 TL'sinin ise Beşiktaş Futbol Yatırımları Sanayi ve Ticaret A.Ş.'ye ait olduğunu gözlemlenmiştir. Beşiktaş Jimnastik Kulübü Derneği’nin borcu, 31 Aralık 2019 tarihi baz alınarak açıklanırken, Beşiktaş Futbol Yatırımları Sanayi ve Ticaret A.Ş.'nin borcu ise 30 Kasım 2019 tarihi baz alınarak açıklanmıştır (Beşiktaş Jimnastik Kulübü, 2020). Ayrıca, halka açık bir şirket statüsünde faaliyet gösteren Beşiktaş Futbol Yatırımları Sanayi ve Ticaret A.Ş.'nin de 29 Şubat 2020 tarihinde sona eren 9 aylık ara döneme ilişkin özet konsolide finansal tablolarının yer aldığı rapor, 09 Nisan 2020 tarihinde Kamu Aydınlatma Platformu (KAP) aracılığıyla paylaşılmıştır. Paylaşılan bu rapora göre, 29 Şubat 2020 itibariyle, Beşiktaş Futbol Yatırımları Sanayi ve Ticaret A.Ş.'nin toplam yükümlülügünün 2.468.429.975 TL olduğu görülmüştür (Beşiktaş Futbol Yatırımları Sanayi ve Ticaret A.Ş., 2020). Söz konusu rakamı, 15 Şubat 2020 tarihinde açıklanan Beşiktaş JK Denetim Kurulu'nun 2019 Yılı 4. Dönem Raporu'nda yer alan Beşiktaş Jimnastik Kulübü Derneği’nin borcu ile birleştirdiğimizde, Beşiktaş Jimnastik Kulübü’nün toplam finansal yükümlülüklerinin 3.072.718.745 TL olduğunu söyleyebiliriz. 
Fenerbahçe Spor Kulübü'nün 08 Şubat 2020 tarihinde yapmış olduğu Olağan Yüksek Divan Kurulu Toplantısı'nda, kulübün nakit çıkışını gerektirmeyecek gelecek aylar ve yıllara ait toplam borcunun 30 Eylül 2019 tarihi itibariyle 2.190.000.000 TL olduğu açıklanmıştır (TRT Spor, 2020). Galatasaray Spor Kulübü'nün ise, 18 Aralık 2019 tarihinde yapmış olduğu Olağan Divan Kurulu Toplantısı'nda, kulübün ve bağlı ortaklıklarının 30 Eylül 2019 itibariyle net borcunun 1.569.000.000 TL olduğu açıklanırken (NTVSpor, 2019), 12 Haziran 2019 tarihinde yapılan Olağan Divan Kurulu Toplantısı'nda, kulübün brüt borcunun 3.019.200.000 TL olduğu açıklanmıştır (CNN Türk Haber, 2019). Baz alınan dönemlerde farklılık olsa da bu verilere 1şığında, üç büyük kulübün toplam borcunun 8.281.918.745 TL, ortalama borcunun ise 2.760.639.582 TL olduğu görülmektedir. Ayrıca açıklanan bu rakamlar, tüm dünyayı ve beraberinde ülkemizi de etkisi altına alan Covid-19 virüsünün henüz ortaya çıkmadığı süreci kapsamaktadır. Söz konusu pandemiden önce finansal anlamda istikrarsız bir görüntü çizen kulüplerin, borç rakamlarının, liglerin durdurulması ve yayıncı kuruluşun da bu süre zarfında herhangi bir ödeme yapmaması sonucu azalan gelirler ile döviz kurlarında yaşanan artışlardan dolayı, önümüzdeki dönemde ciddi derecede bir artış göstereceğini söylemek mümkündür.

Bununla birlikte, açıklanan borç rakamları kamuoyuna açıklanan kısmı kapsamaktadır. Gelir-gider tabloları tam anlamıyla paylaşıma açık olmadığından, diğer bir ifadeyle şeffaflık ilkesi gibi kurumsal yönetim gerekliliklerini tam olarak karşılayamadığından dolayı, gerçek ya da güncel borç rakamlarının ne olduğunu bilmek pek mümkün gözükmemektedir. Ayrıca, borç olarak tabir edilen finansal yükümlülüğü, kendi içerisinde iyi ya da kötü olarak nitelendirmek, doğru bir yaklaşım değildir. Eğer kulüpler, almış oldukları kredileri büyüme ve kalkınmaları açısından kendilerine olumlu bir geri bildirimi olabilecek ve kâr elde edecekleri yatırımlarda kullanırlarsa, bu durum onlar için herhangi bir sıkıntı teşkil etmeyebilir. Fakat buna karşın, söz konusu kredileri getirisi olmayan yatırımlarda kullanırlarsa, bu durum onları özellikle finansal anlamda ciddi bir buhrana sokmaya yetecektir. Yine bu iki durum dışında, sürekli gelir akışı olan ve borçlarını ödeyebilme kapasitesi yüksek olan kulüplerin ise, en azından kısa vadede finansal istikrarı temin edebilecekleri öngörülebilir (Aba, 2018). Öte yandan futbol endüstrisinin yaratmış olduğu konjonktürde başarısız olarak addedilen, Türkiye'deki üç büyük kulübün gelirlerinin, faiz giderlerini bile karşılamaya yetmediği görülmektedir. Söz konusu kulüplerin varlıklarını sürdürebilmeleri, finansal istikrarı sağlamalarına bağlıdır. 


\section{Sonuçlar}

1863 yılında İngiltere Futbol Federasyonu'nun kurulmasıyla birlikte resmi anlamda spor olarak kabul edilen futbol, hızlı bir şekilde tüm dünyaya yayılım göstermiştir. Günümüzde ise popüler kültürün bir yansıması olarak kabul edilen futbol, cazibesiyle insanları peşinden sürüklemekte ve toplumun büyük bir kısmı açısından elzem bir unsur niteliği taşımaktadır. $\mathrm{Bu}$ durum ise, futbolu yüzeysel bir oyun olmanın ötesine taşımış ve içerisinde birçok aktörün barındığı büyük bir endüstri konumuna getirmiştir. Oysa ki ortaya çıkmış olduğu ilk yıllarda, ekonomiden bağımsız bir oyun olarak kabul edilen futbolun, zaman içerisinde endüstriyel bir piyasa haline dönüştüğü görülmektedir. Akşar (2009), söz konusu piyasada futbolun en önemli aktörlerinden biri olarak kabul edilen taraftarların, ilk önce seyirciye, daha sonra da müşteriye dönüştüğünü, kulüplerin arz etmiş olduğu her türlü mal ve hizmete yönelik talebin yapısında da önemli değişiklikler yaşandığını belirtmektedir.

Yaşanılan değişikliklerle birlikte, endüstriyel futbolun beraberinde getirmiş olduğu yasal ve yönetsel gerekliliklere yeterince uyum sağlayamayan ve tam anlamiyla kurumsallaşamayarak profesyonel bir yapıya sahip olamayan birçok kulübün, günümüz itibariyle özellikle finansal anlamda zor bir süreç içerisine girdiği görülmektedir. Bilhassa, bu çalışma kapsamında analiz edilen üç büyük kulüp başta olmak üzere, neredeyse dünyadaki bütün kulüpler, endüstriyel futbolun etkisinden olumsuz olarak etkilenmiş ve borca batık bir duruma gelmiştir. Bugün birçok kulübün elde etmiş olduğu gelirler, borçlarını kapatmaya yetmemekte ve dahası, faiz giderlerini bile karşılamaya imkân tanımamaktadır. Bu durum ise, kulüplerin sürekliliklerini tehlikeye sokarak, onlar için özellikle finansal anlamda ciddi sorunlar teşkil etmektedir.

Profesyonel kulüplerin bünyesinde faaliyet gösteren işletmelerin hem sürekliliklerinin hem de finansal disiplinlerinin sağlanması açısından, finansal performans göstergeleri büyük bir önem arz etmektedir. Özellikle Avrupa futbolundaki en üst düzey yönetim organı olan UEFA'nın, organizasyonlarına katılım şartı olarak kulüplere sunduğu finansal fair-play kriterleri, finansal performansın ne kadar önemli olduğunu gözler önüne sermektedir. Söz konusu uygulamadaki amaç futbolun finansal yapısına rasyonellik ve mali disiplin getirerek, denk bütçe uygulaması aracılığı ile maliyetlerin kontrol edilmesi ve bunun sonucunda da 
kulüpler arasında var olan rekabetçi dengenin gözetilmesidir (Güngör, 2014, s. 136-137). Finansal fair-play kriterlerine uyum sağlayan kulüpler, süreklilikleri açısından herhangi bir tehdit unsuru oluşturmayan daha sağlıklı bir finansal yapıya sahip olurken, söz konusu kriterlere uymayan kulüpler iflas riski ile karşı karşıya kalmaktadır. Bu riskin ortaya çıkmasında ise kulüplerin endüstriyel futbolun gerekliliklerine tam anlamıyla uyum sağlayamamasının yattığ görülmektedir.

Kaynak yönetimi konusunda birbirinden farklı finansal argümanları kullanan kulüpler, borç seviyesinin yüksek olmasından kaynaklanan faiz yükünden, son derecede olumsuz olarak etkilenmektedir. Ayrıca kulüpler, faaliyet açısından kâr elde etmelerine rağmen özellikle uzun vadeli finansman maliyetlerinden dolayı zarar etmektedir. Kulüplerin, futbolun finansmanını disipline edecek daha ussal ve şeffaf bir stratejik eylem planı geliştirmeleri ve etkin maliyet yönetimini sağlamaları elzem bir unsur niteliğindedir. Ayrıca finansal istikrarı temin etmek isteyen kulüplerin, denk bütçe uygulaması aracılığıyla gelir-gider dengesini sağlamaları da mümkün olacaktır (Güngör, 2014, s. 156). Bunun için söz konusu kulüplerin ilk önce "borcun sürdürülebilirliği” ilkesini temel prensip edinmeleri gerekmektedir. Ayrıca yine öyle bir yapı kurulmalıdır ki, kurulacak olan bu yapı içerisinde kulüpler hem sportif faaliyetlerine devam etmeli hem yatırımlarda bulunmalı hem de zaman içerisinde borçlarını sübvanse edebilecek konuma gelmelidir. Ancak bu durumun gerçekleşebilmesi için kulüplerin istikrarlı bir biçimde ve şeffaf bir yönetim anlayışı çerçevesinde yönetilmesi büyük bir önem arz etmektedir.

Bununla birlikte, ülkemizdeki spor kulüplerini yöneten başkan ve yöneticilerin, sadece görev yaptıkları kulüplerin en yetkili organı olan Genel Kurul'a karşı bir sorumluluğu bulunmakta ve yılda bir kere yapılan Genel Kurul toplantılarında ibra edilen yönetimler ise kendilerini mali ve idari anlamda aklamaktadır. Söz konusu yönetimlerin üzerine maddi bir sorumluluk yükleyebilecek herhangi bir cezai yaptırım ya da bir kanun olmadığından, göreve gelen hemen her yönetim plansız bir şekilde harcama yaparak kulüpleri borçlandırmaktadır. Akşar (2011)'a göre, bu durumun önüne ancak finansal piyasalardaki Bankacılık Düzenleme ve Denetleme Kurumu (BDDK) gibi, futbolda da bir üst mali kurulun oluşturulmasıyla geçilebilecektir. Söz konusu kurul, tüm kulüplerin finansal ve ekonomik gelişimleri ile mali yapılarındaki gidişatlarını yakından takip etmeli, denetlemeli ve yön vermelidir. Ayrıca, yine kulüpleri yöneten başkan ve yöneticiler, kendi dönemlerinde yapılan harcamalardan bizzat 
sorumlu olmalı ve ibra edilseler bile, gerektiği takdirde ekonomik anlamda yapmış oldukları işlem ve harcamalardan dolayı hesap vermek durumunda kalabilmelidir. Bu durum, başkan ve yöneticilerin görev süreleri boyunca alacakları kararlarla birlikte, yapacakları tüm harcamaları etkileyecek ve onları çok daha dikkatli bir şekilde hareket etmeye sevk edecektir.

\section{KAYNAKÇA}

Aba, A. (2018, Şubat 4). BirGün Gazetesi. Nisan 8, 2020 tarihinde BirGün Gazetesi Web Sitesi: https://www.birgun.net/haber/dunya-futbol-ekonomisi-ve-finansal-istikrarsizlik202964 adresinden alınd 1

Akbulut, F. (2018, Kasım 25). Prezi. Aralık 6, 2019 tarihinde Prezi Web Sitesi: https://prezi.com/p/oyezwwllo9f9/bir-populer-kultur-urunu-olarak-futbol-ve-futbolcu/ adresinden alınd 1

Akkaya, C. (2008). Küreselleşme ve Futboldaki Dönüşüm. ETHOS: Felsefe ve Toplumsal Bilimlerde Diyaloglar, 1/4, 1-14 .

Akşar, T. (2005). Endüstriyel Futbol. İstanbul: Literatür Yayınları.

Akşar, T. (2005, Aralık). Futbol Ekonomi. Nisan 7, 2020 tarihinde Futbol Ekonomi Web Sitesi: http://www.futbolekonomi.com/index.php/haberler-makaleler/yonetim/117-tugrulaksar/817-futbol-kulueplerinin-irketlemesi-halka-arz-ve-kredilendirilmesi.html adresinden alınd 1

Akşar, T. (2009, Mart 2). Dünya. Ocak 4, 2020 tarihinde https://www.dunya.com/koseyazisi/futbolda-endustriyel-surecin-olmazsa-olmazi-markalasmak/3721 adresinden alınd 1

Akşar, T. (2010). Futbolun Ekonomi Politiği. Literatür Yayıncılık.

Akşar, T. (2011). Türk Futbol Kulüplerinin Finansal Yeniden Yapılanması ve Yönetişimsel Sorunlarına Çözüm Önerileri. TBMM Araştırma Komisyonu'na Sunulan Rapor. http://www.futbolekonomi.com/Raporlar/futbol-ekonomisi.pdf adresinden alınd1

Akşar, T. (2013). Krizdeki Futbol. Literatür Yayıncılık.

Aktaş, H., \& Mutlu, S. (2016). Futbolda Finansal Sürdürülebilirlik Kapsamında "Finansal FairPlay Başa Baş Kuralı” ve Beşiktaş Futbol Kulübü Üzerinde Bir Uygulama. CBÜ Sosyal Bilimler Dergisi, 14(2). 
Alpman, C. (2004). 2004 Avrupa Futbol Sampiyonası. C. Alpman içinde, 2004 Avrupa Futbol Sampiyonası. İstanbul: Bileşim Yayınevi.

Batmaz, H. Ç., Devecioğlu, S., \& Murathan, T. (2017). Türkiye'de Futbolun Kurumsal Değişimi. Spormetre, 15(2).

Beşiktaş Futbol Yatırımları Sanayi ve Ticaret A.Ş. (2020, Nisan 9). Nisan 10, 2020 tarihinde KAP: https://www.kap.org.tr/tr/Bildirim/837058 adresinden alınd1

Beşiktaş Jimnastik Kulübü. (2020). BJK 2019 4. Dönem Denetim Kurulu Raporu. Denetim Raporu, İstanbul. Nisan 4, 2020 tarihinde alındı

Bhandari, R. (2016). Commercialization of European Football. Yüksek Lisans Tezi, Centria University of Applied Sciences, Business Management, Finlandiya.

CNN Türk Haber. (2019, Haziran 12). Nisan 10, 2020 tarihinde CNN Türk Haber Web Sitesi: https://www.cnnturk.com/spor/futbol/galatasarayin-toplam-borcu-aciklandi-4 adresinden alınd 1

Dejonghe, T. (2008). The İmportance of Market Size in The Consumer Service Professional Football: The Belgian Case . International Association of Sports Economists.

Demir, M. (2019). Endüstriyel Futbol ve Futbolda Teknoloji Kullanımı. TRT Akademi, 4(7), 88-103.

Devecioğlu, S., Çoban, B., Karakaya, Y. E., \& Karataş, Ö. (2012). Türkiye'de Spor Kulüplerinin Şirketleşmeye Yönelimlerinin Değerlendirilmesi. SPORMETRE Beden Ĕgitimi ve Spor Bilimleri Dergisi, X(2), 35-42.

Ekmekçi, Y. A., Ekmekçi, R., \& İrmiş, A. (2013). Küreselleşme ve Spor Endüstrisi. Pamukkale Journal of Sport Sciences, 4 (1), 91-117.

Erdoğan, İ. (2008). Futbol ve Futbolu İnceleme Üzerine. İletişim Kuram ve Araştırma Dergisi(26), 1-58.

FIFA. (t.y.). Nisan 9, 2020 tarihinde FIFA Web Sitesi: https://www.fifa.com/associations/ adresinden alınd 1

Gülhan, M. (2019). Futbolun Kültür Kodları. Tekhne Yayınları.

Güngör, A. (2014). Avrupa Futbol Pazarının Ekonomik Boyutu ve Avrupa Futbol Kulüplerinde Finansal Performans Analizi. Ístanbul Gelişim Üniversitesi Sosyal Bilimler Dergisi, 1(2), 134-160. 
Güngör, A. (2014). Futbol Endüstrisinde Sportif Başarı İle Finansal Performans Arasındaki İlişkinin Analizi ve Türkiye Uygulaması. İstanbul Üniversitesi Sosyal Bilimler Dergisi(1), s. 16-36 .

Hür, A. (2002). 4 bin 700 Yıllık Ayak Topu. Popüler Tarih(22).

İnal, A. N. (1998). Futbolda Eğitim ve Öğretim. A. N. İnal içinde, Futbolda Eğitim ve Öğretim (s. 17). Konya: SÜ Basımevi.

Karpavicius, T., \& Jucevicius, G. (2009). The Application of the Business System Concept to the Analysis of Football Business. Inzinerine Ekonomika-Engineering Economics, 3(63), 86-95.

Katırcı, H. (2009). Türk Futbolunda Kurumsal İletişim Yönetimi. Gazi Beden Eğitimi ve Spor Bilimleri Dergisi, XIV(4), 65-75.

Kennedy, P., \& Kennedy, D. (2012). Football Supporters and The Commercialisation of Football: Comparative Responses Across Europe. Soccer \& Society, 13(3).

Kılınç, B. (2008). Kapitalist Bir Etkinlik Olarak Futbolun Büyüsü ve Kahramanları. İletişim Kuram ve Araştırma Dergisi(26), 273-289.

Kiraz, E. (2016). Endüstriyel Futbol Üzerine Bir Araştırma. Turkish Journal of Marketing, 1(2). Krabbenbos, T. (2013). Commercialization Strategies in Football. Yüksek Lisans Tezi, University of Twente, Business Administration, Twente.

Kuper, S. (1996). Futbol Asla Sadece Futbol Değildir (Cilt VII-1). İstanbul: Gençlik Yayınları. Mariotti, F. (2014). Logic of Appropriateness in Football Commercialization: The Case of UEFA Champions League. Yüksek Lisans Tezi, İnternational İnstitute of Social Studies, Hollanda.

Marquez, M., \& Martin, H. (2001). The New Football Business: A Challenge for Elite Followers - A Case Study for IFK Göteborg. Yüksek Lisans Tezi, Göteborg Üniversitesi, İşletme Bölümü, Göteborg.

NTVSpor. (2019, Aralık 18). Nisan 8, 2020 tarihinde NTVSpor Web Sitesi: https://www.ntvspor.net/futbol/galatasaray-in-borcu-aciklandi5dfa24bef4416015d4257fb0?_ref=infinity adresinden alınd1

Saban, M., \& Demirci, F. (2016). Finansal Fair Play ve Türkiye'deki Dört Büyük Futbol Kulübünün Uyum Düzeyinin İncelenmesi. Mali Çözüm Dergisi - ISMMMO, Eylül $\operatorname{Ekim}(137)$. 
Schoop, F. B. (2016). Football Sponsorship Market: Danish Perspective. Yüksek Lisans Tezi, Universidade de Lisboa, ISCTE Business School, Portekiz.

Sert, M. (2000). Gol Atan Galip Futbola Sosyolojik Bir Bakış. M. Sert içinde, Gol Atan Galip Futbola Sosyolojik Bir Bakış. İstanbul: Bağlam Yayınları.

Talimciler, A. (2008). Futbol Değil İş: Endüstriyel Futbol. Iletişim Kuram ve Araştırma Dergisi(26), 89-114.

Talimciler, A. (2010, Kasım 25). Şubat 10, 2020 tarihinde Futbol Ekonomi: http://www.futbolekonomi.com/index.php/haberler-makaleler/genel/259-ahmettalimciler/1043-br-merulatirma-araci-olarak-futbolun-tuerkyede-son-25-yili.html adresinden alınd 1

Talimciler, A. (2017). Futbol taraftarlığındaki erkeklik imgesi: Bucaspor, Göztepe ve Karşıyaka taraftarları üzerine bir inceleme. Journal of Social Sciences and Humanities, $1(1), 27-57$.

TDK. (tarih yok). 12 4, 2019 tarihinde Türk Dil Kurumu Sözlükleri: https://sozluk.gov.tr/?kelime=futbol adresinden alındı

TDK. (tarih yok). Türk Dil Kurumu Sözlükleri. Şubat 25, 2020 tarihinde Türk Dil Kurumu Sözlükleri: https://sozluk.gov.tr/?kelime=te adresinden alındı

TRT Spor. (2020, Şubat 8). Nisan 4, 2020 tarihinde TRT Spor Web Sitesi: https://www.trtspor.com.tr/haber/futbol/super-lig/fenerbahcenin-borcu-aciklandi202701.html adresinden alınd 1

Tutal, E. (2013). Spor Kulüplerinin İsim Hakkı ve Haciz Yasağı. Uyuşmazlık Mahkemesi Dergisi, 2(2), s. 271-299.

Türkbal, A. (1983). Fiyat Teorisi (Mikroiktisat) (Genişletilmiş ve Geliştirilmiş II. Baskı b.). Erzurum: Atatürk Üniversitesi Yayınları No. 622.

Türkiye Kurumsal Yönetim Derneği. (2010). Kurumsal Yönetim İlkeleri Işı̆̆ıında Türk Futbol Kulüpleri Yönetim Rehberi. İstanbul: Caretta Yayınc1lık.

UEFA. (2019, Ocak 23). Nisan 9, 2020 tarihinde UEFA Web Sitesi: https://www.uefa.com/insideuefa/about-uefa/history/ adresinden alınd1

Uluyol, O. (2014). Süper Lig Futbol Kulüplerinin Finansal Performans Analizi. Journal of Yasar University, 9(34). 
FSECON YILMAZ, A. H. (2020), “Endüstriyel Futbolda Finansal İstikrartn Önemi”, Fiscaoeconomia, Vol.4(2), 498-523.

Vikipedi. (t.y.). Şubat 28, 2020 tarihinde Vikipedi Özgür Ansiklopedi: https://tr.wikipedia.org/wiki/FIFA adresinden alınd1

Wahl, A. (2005). Ayaktopu: Futbolun Öyküsü. İstanbul: Yapı Kredi Yayınları.

Yiğit, E. (2012). Kapitalizm Sürecinde Futbolun Ticarileşmesi. Yüksek Lisans Tezi, İstanbul. Yurdesin, D. (2005). Futbol, Kamusal Alan ve Demokrasi. Toplum ve Bilim(103), 107-120. 